\section{Cytotoxicity and Inflammatory Mediators Release by Macrophages Exposed to Real Seal XT and Sealapex Xpress}

Léa Assed Bezerra da Silva ${ }^{1} \mathbb{D}$, Lídia Regina da Costa Hidalgo ${ }^{1} \mathbb{D}$, Manoel Damião de Sousa-Neto ${ }^{1} \mathbb{D}$, Maya Fernanda Manfrin Arnez ${ }^{1} \mathbb{D}$, Frederic

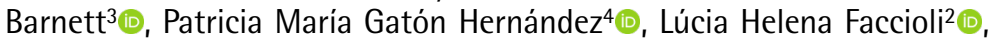
Francisco Wanderley Garcia Paula-Silva ${ }^{1,2}$ [D

\author{
'Department of Paediatric Clinics, \\ School of Dentistry of Ribeirão \\ Preto, USP - Universidade de São \\ Paulo, Ribeirão Preto, SP, Brazil \\ ${ }^{2}$ Departamento de Análises \\ Clínicas, Toxicológicas e \\ Bromatológicas, Faculdade de \\ Ciências Farmacêuticas de Ribeirão \\ Preto, USP - Universidade de São \\ Paulo, Ribeirão Preto, SP, Brazil \\ ${ }^{3}$ Department of Dental Medicine, \\ Albert Einstein Medical Center, \\ Philadelphia, PA, USA \\ ${ }^{4}$ Universitat de Barcelona, \\ Barcelona, Spain
}

Correspondence: Prof. Dr. Francisco Wanderley Garcia Paula-Silva, Avenida do Café, s/n 14040904, Ribeirão Preto, SP, Brasil. Tel: 55+16-3315-4113. e-mail: franciscogarcia@forp.usp.br

Key Words: cytotoxicity, Sealapex Xpress, Real Seal XT, macrophages, cytokines.

\section{Introduction}

Adequate root canal shaping and sealing are fundamental to the success of endodontic therapy (1). The physical, chemical, and biological properties of root canal filling materials should create a hermetic seal between the root canal system and the periapical tissues and induce closure of the root apex and deposition of mineralized tissue (2-6). Thus, the nature of the root canal sealer placed in direct contact with the apical and periapical connective tissue is crucial for inducing proper biological sealing. Non-compatible materials can cause an irritation to tissues and inhibit the repair process due to induction of harmful components of the inflammatory response (7-9).

Several endodontic sealers have been placed in the market; recently, two root canal sealers have been modified to generate materials with improved physical, chemical, and biological properties: the calcium hydroxide-based Sealapex Xpress (SybronEndo, Orange, CA, USA) $(2,7,10,11)$ and the auto-etch 2-hydroxyethyl methacrylate and epoxy resin Real Seal XT (SybronEndo) $(2,7)$. Understanding the biological effects of root canal sealers is imperative because the cytotoxicity of these materials varies considerably depending on their composition (12).

The cytotoxicity of dental materials can be tested in cell culture models, which is a low cost, fast, reliable, and reproducible method $(10,13)$. Macrophages have been widely used in cytotoxicity studies because they are highly sensitive to toxic materials, are found in the periapical microenvironment, and recruited during the inflammatory response (14). When stimulated, macrophages are activated and produce pro- or anti-inflammatory cytokines and mediators depending on the nature of the stimuli $(15,16)$. However, the effect of Sealapex Xpress and Real Seal XT sealers on the activation of macrophages and the generation of pro- or anti-inflammatory mediators have not been investigated. Thus, this study evaluated the in vitro cytotoxicity of root canal sealers Sealapex Xpress and Real Seal XT by MTT assay and their effect on activating J774.1 macrophages to secrete cytokines. We hypothesize that both sealers would not be cytotoxic neither activate macrophages to secret cytokines.

\section{Material and Methods}

\section{Preparation of Extracts}

This study was conducted in accordance with the standards of the International Organization for Standardization (ISO 10993-5: 2009) (17).

To obtain $10 \mathrm{mg}$ of each material, Sealapex Xpress and 
Real Seal XT were placed on sterile paper and weighed under natural light using a PG 503-S scale (Mettler Toledo, Columbus, OH, USA). Manipulation was performed in a laminar flow cabinet according to the manufacturer's recommendations. Next, freshly prepared sealers were diluted in $1 \mathrm{~mL}$ of Dulbecco's Modified Eagle Medium (DMEM, Gibco, Grand Island, NY, USA) for $48 \mathrm{~h}$ at $4{ }^{\circ} \mathrm{C}$. A serial dilution was prepared from the initial solution $(10 \mathrm{mg} / \mathrm{mL})$ to achieve final concentrations of $1.0 \mathrm{mg} / \mathrm{mL}$ and $0.1 \mathrm{mg} / \mathrm{mL}$.

\section{Cell Culture}

The J774.1 murine macrophage cell line was obtained from the American Type Culture Collection (ATCC, Rockville, $M D, U S A)$. The cells were grown in DMEM medium supplemented with 10\% fetal bovine serum (FBS) and $1 \%$ penicillin/streptomycin. After the formation of a monolayer, cells were harvested with plastic cell scrapers and centrifuged at $1,500 \mathrm{rpm}$ for $10 \mathrm{~min}$ at $10{ }^{\circ} \mathrm{C}$ using a microcentrifuge. After centrifugation, supernatants were discarded and $10 \mathrm{ml}$ of DMEM were added to each tube of cells. The total number of cells was counted and cell viability was determined by staining cells with trypan blue (Gibco) and counting live (unstained) and dead (stained) cells using a Neubauer chamber (BOECO Germany, Hamburg, Germany).

Then, the cells were plated in 96-well culture plates (Corning Glass Works, Corning, NY, USA) at a density of $1 \times 10^{5}$ cells/well and incubated overnight in DMEM in $5 \% \mathrm{CO}_{2} / 95 \%$ air at $37{ }^{\circ} \mathrm{C}$. Next, cell culture media were removed and $200 \mu \mathrm{L}$ of resin extracts was added to the wells and plates were incubated for 24 and $48 \mathrm{~h}$. The supernatant was collected and stored at $-20{ }^{\circ} \mathrm{C}$ for cytokine quantification.

\section{Cytotoxicity Assay}

J774.1 cell viability was evaluated using the 3-(4,5-dimethylthiazol-2-yl)-2,5-diphenyltetrazolium bromide (MTT) colorimetric assay (Sigma-Aldrich, St. Louis, MO, USA). Cells were incubated with composite resin extracts for 24 and $48 \mathrm{~h}$. Next, the cultures were incubated with 5\% MTT in Roswell Park Memorial Institute (RPMI) medium for $3 \mathrm{~h}$. Following incubation, $50 \mathrm{ml}$ of $20 \%$ sodium dodecyl sulfate (SDS) in $0.01 \mathrm{M} \mathrm{HCl}$ were added to each well and plates were maintained at room temperature until complete solubilization of the precipitate. The absorbance was measured at $570 \mu \mathrm{m}$ using a spectrophotometer ( $\mu$ Quanti, Bio-Tek Instruments, Inc., Winooski, VT, USA) and was directly proportional to cell viability. The cytotoxicity of root canal sealers was expressed as percentage cytotoxicity relative to unstimulated cells (negative control) and cells stimulated with dimethyl sulfoxide (DMSO; positive control).

\section{Cytokine Detection}

The concentrations of IL- 6, IL-10, IL- 4 , and TNF- $\alpha$ in culture supernatants were quantified by ELISA using specific purified and biotinylated antibodies and cytokine standards according to the manufacturer's instructions ( $R$ \&t D Systems, Minneapolis, MN, USA). The optical densities were measured at $405 \mu \mathrm{m}$ using a microplate reader ( $\mu$ Quanti). The cytokine concentrations were determined using a standard curve established with the appropriate recombinant cytokine (expressed in $\mathrm{pg} / \mathrm{mL}$ ).

\section{Statistical Analysis}

Data are presented as means \pm SEM (standard error of the mean). Differences were determined using one-way analysis of variance (ANOVA) followed by the Tukey's test. Tests were performed using the Graph Pad Prism 6.0 statistical software (Graph Pad Software Inc., San Diego, CA, USA) and the significance level was set at 5\%.

\section{Results}

\section{Sealapex Xpress and Real Seal XT Cytotoxicity}

Cell viability was not affected by treatment with 0.1 or $1 \mathrm{mg} / \mathrm{mL}$ of either Sealapex Xpress or Real Seal XT extracts ( $p>0.05)$. However, cell viability after treatment with $10 \mathrm{mg} / \mathrm{mL}$ of either Sealapex Xpress or and Real Seal $\mathrm{XT}$ was significantly lower compared to treatment with medium alone $(p<0.05)$, and similarly to that found for DMSO ( $p>0.05$ ). Additionally, no significant difference in cell viability was found between the two materials after 24 and $48 \mathrm{~h}$ ( $p>0.05$; Fig. 1A, 1B).

\section{Cytokine Production Upon Treatment with Sealapex Xpress And Real Seal XT}

Because the $10 \mathrm{mg} / \mathrm{mL}$ extracts of both materials and DMSO were cytotoxic, cytokine detection was performed in the supernatant of cells maintained in cell culture without stimuli (negative control) or treated with 0.1 or $1.0 \mathrm{mg} / \mathrm{mL}$ of Sealapex Xpress and Real Seal XT.

Sealapex Xpress inhibited the production of TNF- $\alpha$, whereas Real Seal XT induced TNF- $\alpha$ secretion at $24 \mathrm{~h}$ $(p<0.05$, Fig. 2A). Similarly, IL- 6 production was induced by Real Seal XT $(p<0.05)$, but not by Sealapex Xpress $(p>0.05$, Fig. 2B). While IL-10 was not detected in cells maintained in medium without stimulation at $24 \mathrm{~h}$, treatment with Real Seal XT and Sealapex Xpress induced the secretion of this cytokine. Additionally, IL-10 levels were significantly higher in cells treated with Sealapex Xpress than with Real Seal XT ( $p<0.05$, Fig. 2). IL-4 was not detected in any group.

\section{Discussion}

In this study, we evaluated the cytotoxicity of Sealapex Xpress and Real Seal XT and their ability to activate J774.1 
macrophages as measured by the secretion of pro- and anti-inflammatory cytokines. We partially accepted the null hypothesis, since Sealapex Xpress and Real Seal XT root canal sealers had low cytotoxicity at 24 and $48 \mathrm{~h}$. However, Sealapex Xpress inhibited TNF- $\alpha$ production and induced higher IL-10 expression compared to Real Seal XT. Conversely, Real Seal XT induced IL-6 secretion, whereas Sealapex Xpress had no significant effect on production of this cytokine.

Cytotoxicity was determined using the MTT assay, a common method for determining the cytotoxicity of endodontic materials (18). The cytotoxicity of Real Seal XT has been assessed in a culture of mouse fibroblasts (L929) and this material was shown to be less cytotoxic than AH Plus (19). In this study, we used J774.1 macrophages, which are directly involved in the inflammatory process and represent an interesting model to investigate the pro- and anti-inflammatory response to different sealing materials. It has been demonstrated that extracts from RealSeal SE and RealSeal XT are cytotoxic to macrophages when used in a dilution of 1:2 and 1:20 (extract:medium), respectively $(7,14)$ which is in agreement with the higher concentration used in this study. On the other hand, lower concentration induced no cytotoxicity as previously reported (7). A study that evaluated the original Sealapex formulation reported increased production of pro-inflammatory mediators such as iNOS, IL- $1 \alpha$, TNF- $\alpha$, IL- 6 , and IL-8 compared to MTA and
Filapex cements (20). Conversely, Silva et al. (15) reported that Sealapex did not stimulate peritoneal macrophage cells to release TNF- $\alpha$.

Macrophage activation is one of the factors that determine the severity of the inflammatory process, because macrophages orchestrate both the onset and the resolution of inflammation. Depending on the nature of the stimuli, activation of macrophages results in the expression of different pro- and anti-inflammatory mediators (21). Because macrophages are innate immune cells with wellestablished roles in the primary response to pathogens, as well as in tissue remodeling, coordination of the adaptive immune response, and during the entire inflammatory process (22), the findings of this study suggest that differential modulation of macrophage activation could affect cell function. Sealapex Xpress inhibited TNF- $\alpha$ and did not modulate IL-6, which are important pro-inflammatory cytokines. RealSeal, on the other hand, stimulated both. Nonetheless, both induced anti-inflammatory IL-10. The impact of that in vivo is difficult to ascertain due to inherent limitations of in vitro studies, but indicates that Sealapex Xpress could improve regulation of inflammatory reaction apically.

Limitations of this in vitro study include the fact that it was not possible to mimetize the microenvironment of periapical region and the pleiotropic network of cells and molecules produced within it and the fact that culture
A $24 \mathrm{~h}$
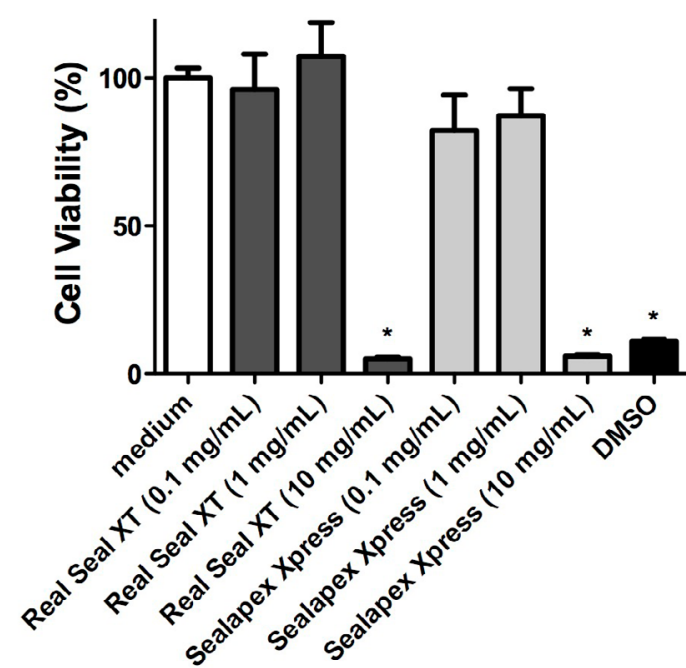

B

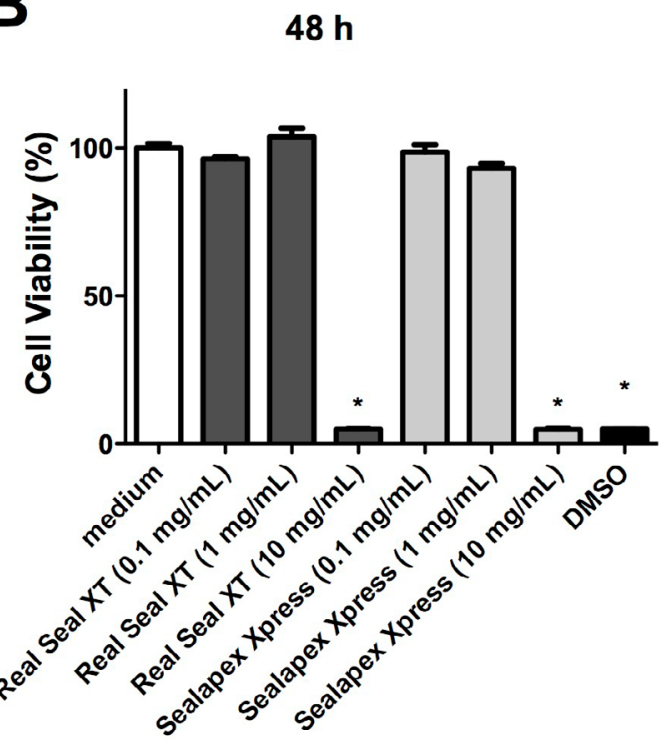

Figure 1. Effect of different concentrations of Sealapex Xpress and Real Seal XT on cell viability of murine J774.1 macrophages by the MTT assay after 24 (A) and 48 (B) h. Significant differences to the negative control group (cells incubated with cell culture medium only) are indicated by * $(\mathrm{p}<0.05)$. Independent experiments $(n=2)$ were done in triplicate 
conditions can modify gene expression, protein synthesis and their degradation, among others (23). Of interest, in vivo studies have demonstrated that endodontic sealers

A

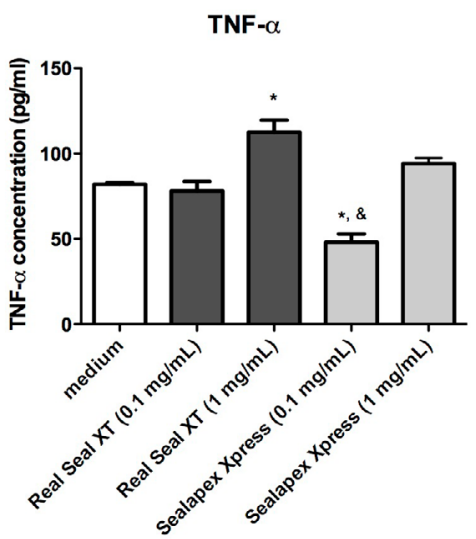

B

IL-6

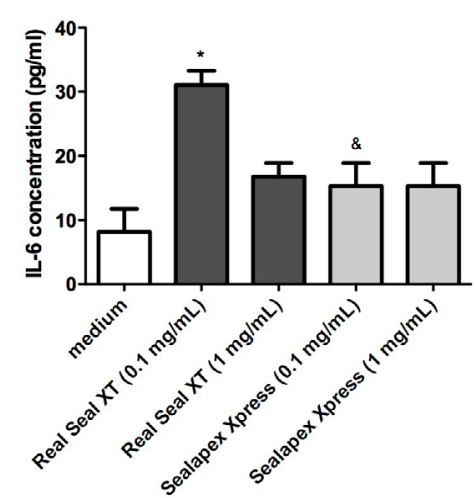

C

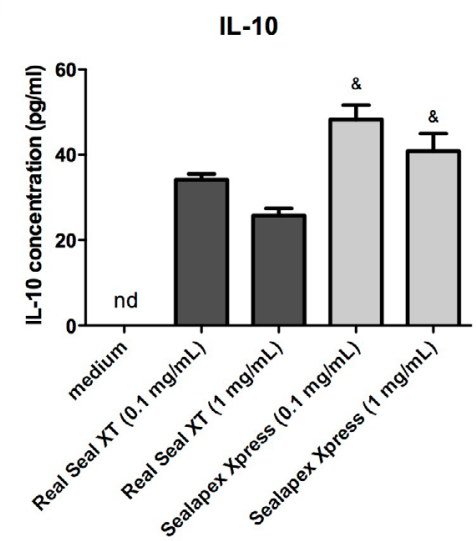

Figure 2. Effect of different concentrations of Sealapex Xpress and Real Seal XT on the secretion of TNF- $\alpha$ (A), IL-6 (B), and IL-10 (C) by murine J774.1 macrophages, as assessed by ELISA after incubation for $24 \mathrm{~h}$. Significant differences to the negative control group (cells incubated with culture medium only) are indicated by" $(\mathrm{p}<0.05)$ and significant differences between Sealapex Xpress and Real Seal XT $(0.1 \mathrm{mg} / \mathrm{mL}$ or $1.0 \mathrm{mg} / \mathrm{mL})$ are indicated by\& $(\mathrm{p}<0.05)$. Independent experiments $(\mathrm{n}=2)$ were done in triplicate
Real Seal XT and Sealapex Xpress showed satisfactory biocompatibility when implanted in subcutaneous tissue of mice $(7,11)$ and when used for root canal filling in dogs teeth where they induced a complete apical sealing with deposition of newly formed mineralized tissue (2).

Here, we showed that both sealers have low toxicity but differentially activate macrophages. We speculate that the downregulation of inflammatory mediators in the periapical milieu after treatment with Sealapex Xpress may have affected tissue remodeling, resulting in increased mineralization in vivo (2). The differential activation of macrophages found in this study may help understand the underlying mechanisms of mineralized tissue formation following inflammatory stimuli.

The results of this study showed that both sealers are not cytotoxic but differently activated macrophages. Macrophage activation by SealapexXpress was characterized by inhibition of TNF- $\alpha$ and increase of IL-10, whereas Real Seal XT induced IL-6.

\section{Resumo}

0 objetivo deste estudo foi avaliar in vitro a citotoxicidade dos cimentos endodônticos Sealapex Xpress e Real Seal XT pelo ensaio de MTT e a ativação de macrófagos J774.1. Os cimentos endodônticos Sealapex Xpress e Real Seal XT foram pesados e os extratos foram obtidos a partir da diluição em meio de cultura DMEM por 48 horas $(10 \mathrm{mg} / \mathrm{mL}, 1 \mathrm{mg} / \mathrm{m}$, e $0,1 \mathrm{mg} / \mathrm{mL}$ ). A viabilidade celular foi avaliada pelo ensaio MTT e a produção de citocinas (TNF- $\alpha$, IL-6 e IL-10) foi investigada pelo ensaio imunoenzimático (ELISA) em células de linhagem (macrofagos J774.1). Os dados obtidos foram analisados utilizando-se análise de variância de uma via e pós-teste de Tukey $(\alpha=0,05)$. A viabilidade celular após 24 ou 48 horas não foi afetada nas concentrações de 0,1 ou $1 \mathrm{mg} / \mathrm{mL}$ dos dois cimentos estudados $(p>0,05)$. Por outro lado, na concentração $10 \mathrm{mg} / \mathrm{mL}$, a viabilidade celular foi significativamente mais baixa $(p<0,05)$. Observouse que o Sealapex Xpress inibiu a produção de TNF- $\alpha$, enquanto o Real Seal XT induziu a secreção de TNF- $\alpha$ às $24 \mathrm{~h}(\mathrm{p}<0,05)$. A produção de IL-6 foi induzida pelo Real Seal XT, mas não pelo Sealapex Xpress $(p<0,05)$. A secreção da citocina anti-inflamatória IL-10 foi induzida tanto pelo Real Seal XT quanto pelo Sealapex Xpress. IL-4 não foi detectada em nenhum grupo. Em conclusão, os dois cimentos obturadores apresentaram baixa toxicidade, mas ativaram os macrófagos de modo distinto. A ativação pelo Sealapex Xpress foi caracterizada pela inibição do TNF- $\alpha$ e indução da IL-10, enquanto o Real Seal XT induziu somente IL-6.

\section{Acknowledgements}

The authors deny any conflicts of interest. This study was partially supported by São Paulo Research Foundation (FAPESP) Grant \#2019/00204-1 to FWGPS and Fellowship \#2012/10238-1 to LRCH.

\section{References}

1. Prado M, Simão RA, Gomes BP. A microleakage study of gutta-percha/ AH Plus and Resilon/Real self-etch systems after different irrigation protocols. J Appl Oral Sci 2014;22:174-179.

2. Silva LA, Barnett F, Pumarola-Suñé J, Cañadas PS, Nelson-Filho P, Silva RA. Sealapex Xpress and RealSeal XT feature tissue compatibility in vivo. J Endod 2014;40:1424-1428.

3. Leonardo MR, Flores DS, de Paula E Silva FW, de Toledo Leonardo R, da Silva LA. A comparison study of periapical repair in dogs' teeth using Roeko Seal and AH plus root canal sealers: the histopathological 
evaluation. J Endod 2008;34:822-825.

4. Leonardo MR, Silva LA, Utrilla LS, Assed S, Ether SS. Calcium hydroxide root canal sealers - histopathologic evaluation of apical and periapical repair after endodontic treatment. J Endod 1997;23:428-432.

5. Gomes-Filho JE, Moreira JV, Watanabe S, Lodi CS, Cintra LT, Dezan Junior E, Bernabé PF, Nery MJ, Otoboni Filho JA. Sealability of MTA and calcium hydroxidecontaining sealers. J Appl Oral Sci 2012;20:347-351.

6. Wong JG, Caputo AA, Li P, White SN. Microleakage of adhesive resinous materials in root canals. J Conserv Dent 2013;16:213-218.

7. Silva LAB, Azevedo LU, Consolaro A, Barnett $F, X u Y$, Battaglino RA, et al. Novel endodontic sealers induce cell cytotoxicity and apoptosis in a dose-dependent behavior and favorable response in mice subcutaneous tissue. Clin Oral Investig 2017;21:2851-2861.

8. Queiroz AM, Assed S, Consolaro A, Nelson-Filho P, Leonardo MR, Silva RA, et al. Subcutaneous connective tissue response to primary root canal filling materials. Braz Dent J 2011;22:203-211.

9. Benetti F, Queiroz IOA, Cosme-Silva L, Conti LC, Oliveira SHP, Cintra LTA. Cytotoxicity, Biocompatibility and Biomineralization of a New Readyfor-Use Bioceramic Repair Material. Braz Dent J 2019;30:325-332.

10. Scelza MZ, Coil J, Alves GG. Effect of time of extraction on the biocompatibility of endodontic sealers with primary human fibroblasts. Braz Oral Res 2012;26:424-430.

11. da Silva $L A B$, Bertasso AS, Pucinelli $C M$, da Silva RAB, de Oliveira $K M H$, Sousa-Neto MD, et al. Novel endodontic sealers induced satisfactory tissue response in mice. Biomed Pharmacother 2018;106:1506-1512.

12. Bueno CR, Valentim D, Marques VA, Gomes-Filho JE, Cintra LT, Jacinto $\mathrm{RC}$, et al. Biocompatibility and biomineralization assessment of bioceramic-, epoxy-, and calcium hydroxide-based sealers. Braz Oral Res 2016;30(1). pii: S1806-83242016000100267.

13. Beltes $P$, Koulaouzidou E, Kotoula V, Kortsaris AH. In vitro evaluation of the cytotoxicity of calcium hydroxide-based root canal sealers. Endod
Dent Traumatol 1995;11:245-249.

14. Graunaite I, Lodiene G, Arandarcikaite O, Pukalskas A, Machiulskiene V. Leachables and cytotoxicity of root canal sealers. J Oral Sci 2018;60:381-387.

15. Silva LA, Leonardo MR, Faccioli LH, Figueiredo F. Inflammatory response to calcium hydroxide based root canal sealers. J Endod 1997;23:86-90.

16. Mosser DM, Edwards JP. Exploring the full spectrum of macrophage activation. Nat Rev Immunol 2008;8:958-969.

17. International Organization for Standartization (ISO): IS0109935:2009. Biological evaluation of medical devices - tests for in vitro cytotoxicity. Switzerland;2009.

18. Huang TH, Ding SJ, Hsu TZ, Lee ZD, Kao CT. Root canal sealers induce cytotoxicity and necrosis. J Mater Sci Mater Med 2004;15:767-771.

19. Cotti E, Petreucic V, Re D, Simbula G. Cytotoxicity evaluation of a new resin-based hybrid root canal sealer: an in vitro study. J Endod 2014;40:124-128.

20. Gea-Sorli S, Closa D. Role of macrophages in the progression of acute pancreatitis. World J Gastrointest Pharmacol Ther 2010;1:107-111.

21. Mantovani A, Sica A, Locati M. New vistas on macrophage differentiation and activation. Eur J Immunol 2007;37:14-16.

22. Martinez FO, Helming L, Gordon S. Alternative activation of macrophages: an immunologic functional perspective. Annu Rev Immunol 2009;27:451-483.

23. Jedrzejczak-Silicka M. History of Cell Culture. In: New Insights into Cell Culture Technology. London: IntechOpen; 2017.

Received March 13, 2020 Accepted May 29, 2020 